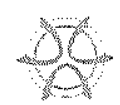

PLANNING MALAYSIA

Journal of the Malaysian Institute of Plamers (2008) VI, $57-73$

\title{
TOWARDS A SAFE PLACE FOR CHILDREN IN TODAY'S RESIDENTIAL NEIGHBOURHOODS
}

\author{
Ali A. Alraouf ${ }^{1}$ \\ Department of Architecture, College of Engineering \\ UNIVERSITY OF BAHRAIN
}

\begin{abstract}
Most Arab cities are experiencing tremendous urbanization processes and challenges. Despite the fact that Arab cities are developing fast, social factors in planning and urban design have been neglected. Many of the urban problems that Arab cities experience today result from an unbalanced approach to development, where physical development has been given priority over spiritual, cultural, and social requirements. The concern of the societal needs in urban planning and design is often intended for adults regardless of the growing number and needs of the younger population. This paper focuses on children because their needs are the least considered in planning and design of cities.

The paper motivates urban authorities, of the Arab world, to be sensitive to the needs of urban children and to find suitable tools and mechanisms to consider children in their strategic and physical planning process. Towns and cities must be made safe and children friendly. This paper discusses the various forces that influence Arab children in the wake of industrialization, urbanization, modernization, and globalization. It will specifically focus on diverse social and cultural ills that have emerged among Arab children, which are attributed to living in a stressful physical environment, one that neglects their needs and marginalizes their existence in the fabric of the developing cities. This paper will address the following questions: why are cities not planned with the needs of children in mind? What are the characteristics of cities that are positive for children? In addition, the paper calls for a more holistic approach to planning and rephrasing the role of urban planners and designers in producing spaces and places for Arab children where they will enjoy their growing cities and neighborhoods.
\end{abstract}

Keywords: Strategic Planning, Children Places, Arab Cities, Children Environment, Urban Theories.

\footnotetext{
'Associate Professor, Architecture Department, College of Engineering, University of Bahrain, Bahrain (alialraouf(ayahoo.com).
} 


\section{INTRODUCTION}

Around the globe, cities are expanding at an incredible pace and the future of the developing world will be increasingly urban. In the coming years, cities will be "home" to more and more children and by the year 2025, 6 out of every 10 children will live in urban areas (UNICEF, 2007).

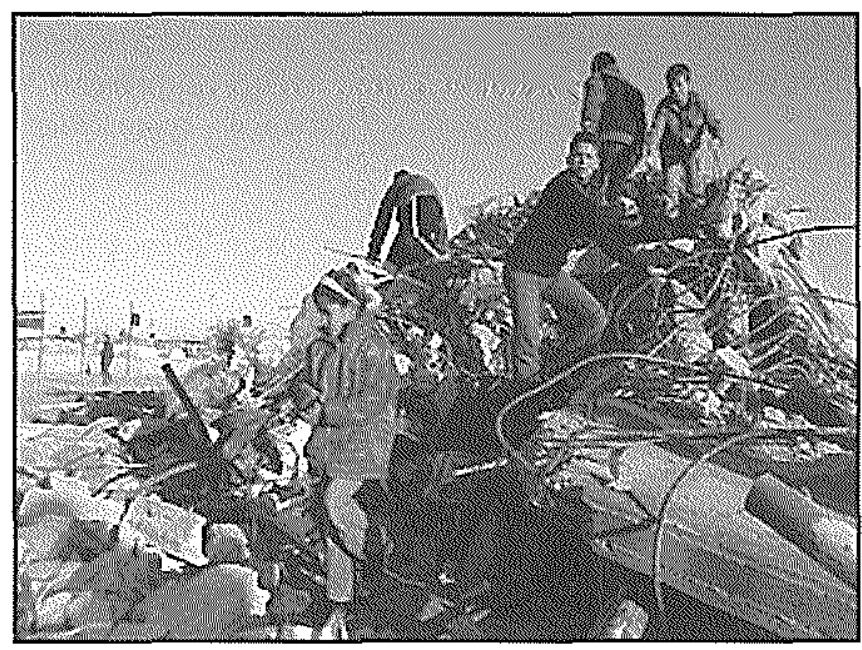

Figure 1: Children are in great need for safe playing areas.

Innovative strategies, approaches and mechanisms have to be developed and implemented to ensure creating environments that are based on cooperation at different levels, crossing national and local borders and barriers of social groups. This is a global movement for children that aim to generate new momentum and political commitment in giving priority and attention to children.

\section{CHILDREN²: A SEARCH FOR IDENTITY}

In the context of this discussion, a critical factor is whether or not children are able to function on their own within the city, or whether they are completely or relatively dependent on adults. Cultural attitudes towards children as a group vary in terms of whether they are welcomed, tolerated, or un-welcomed in

\footnotetext{
${ }^{2}$ Children generally defined as anyone under the age of 18 . In term of maturity, children are those who have not yet reached full intellectual or social maturity (Simpson, 1999).
} 
public space, and in their values as to whether the independence of children is a goal, a necessity, or something to be discouraged.

The socio-physical environment of the city in all of its aspects; how it facilitates and encourages, and how it hinders or excludes use by children is a significant factor, and is the focus of this paper. But why should children be singled out for attention here? Children are a significant proportion of the population in countries all over the world. Table 1 shows that children form almost half of the population in major selected world cities. The table also presents the extreme differences in health between selected countries as represented by infant mortality.

Table 1: Comparative statistics on the condition of children, UNICEF (2007)

\begin{tabular}{|c|c|c|}
\hline Country & Percent of children in & Infant mortality (per 1000 \\
\hline population & live births) \\
\hline Ethiopia & a & \\
\hline Syria & 52.5 & 118 \\
\hline Egypt & 50.3 & 25 \\
\hline Bahrain & 43.3 & 41 \\
\hline UAE & 58 & - \\
\hline USA & 57 & - \\
\hline France & 26 & 7 \\
\hline Spain & 23 & 5 \\
\hline Japan & 18.9 & 6 \\
\hline
\end{tabular}

Obviously, children can be more seriously affected by their living environment compared to adults because of their greater vulnerability to disease and environmental hazards. It is also important to investigate and examine the process whereby young children discover and map their surroundings, imprinting locations with memories and associations which in turn help to mould their own sense of identity (Christensen, 2002). Paying attention to what children really need often means different priorities and different standards for local authorities, decision makers, and city designers.

\section{PLACE: PHYSICAL AND SYMBOLIC DIMENSIONS}

The main question of this paper is to investigate the processes by which children can have a place in their cities. The notion of 'place' is meant in 
physical and symbolic terms. Physically, are there places where children can enjoy themselves and feel safe? Symbolically, does the city through its design and planning and through the attitudes and behaviors of the adults transmit a message to children that they are welcomed, and that they are an equal part of the society in the city?

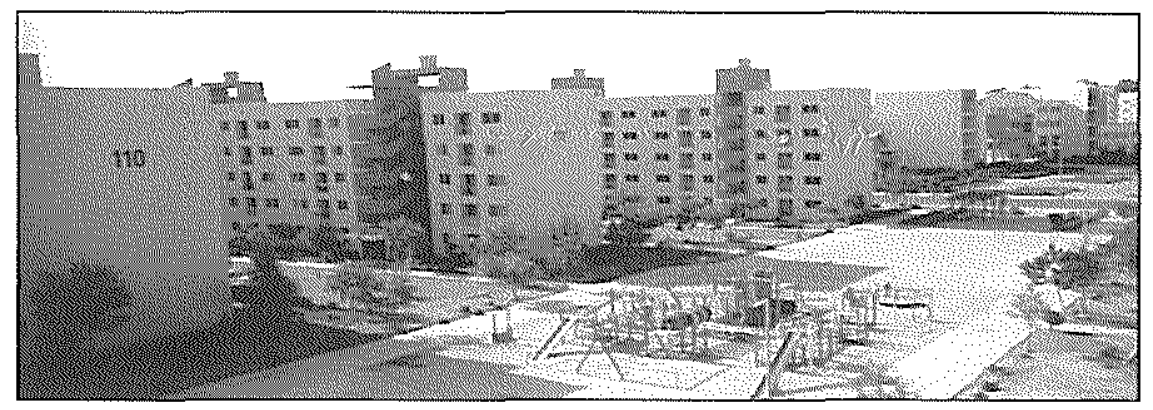

Figure 2: Ill-defined children spaces are contributing to the problem of isolated children.

The crucial question is why children are not considered properly in the process of planning and developing cities. Adults in general and politicians, planners, and city managers, in particular, too often ignore the fact that the city is relevant to the lives of children. Adults do not understand the developmental importance of various experiences, such as playing for children. For some of them, the attitude is that childhood is a passing phase, and thus need not to be considered separately (Churchman, 1999). Furthermore, children are usually not given an opportunity to say what they want and need, particularly in the public arena (Spencer \& Woolley, 1998)

\section{THE GROWTH OF CHILDREN IN ARAB PHYSICAL SETTINGS}

In the last decade, most of the Arab cities and precisely Gulf cities are experiencing an unprecedented development and growth. This tremendous growth of contemporary Arab cities has its positive and negative aspects. In terms of the physical environment, the size and scale of many Arab cities have increased vastly. The assumption was that this kind of growth does make a difference in the lives of children. Eventually, cities like Dubai, Doha, Manama, Cairo, among others ended up with a vast urban development based on economical, industrial or tourism activities. Related to this is the fact that rates of car ownership and the number of cars on the roads have also significantly increased, and this clearly has implications for the safety of children and for 
their ability to use the streets in various ways on their own. So Arab cities are definitely developing but not in the direction which focus on and consider children as part of the city's inhabitants and dwellers.

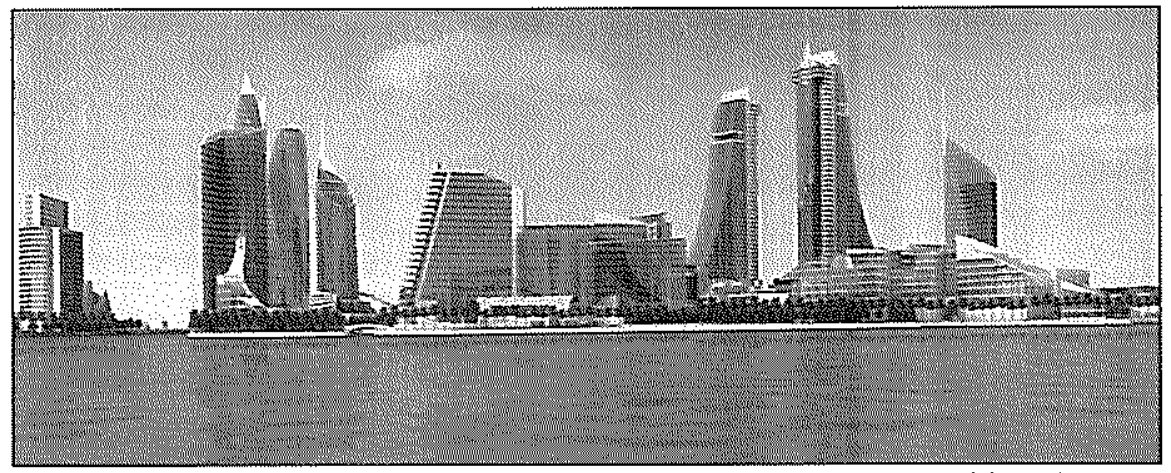

Figure 3: Large scale urban development in contemporary Arab cities, the case of Bahrain.

Arab cities are competing today to create the largest, the tallest and the biggest physical settlements and environments. Examples like Bahrain's financial harbor, or Qatar's water front development, or Dubai's tower are evidences of these cities' growth scale.

The growth of cities and the mechanization of transport raise fears about the safety of children ${ }^{3}$, particularly those children who play in the streets. Cahill (1990) argued that because of this virtual banishment of the young from many public places, public accommodations were seldom designed with them in mind. Among other things, water fountains, toilets, and public telephones were and are still built too high for young children to reach. Once again, although children may also be pedestrians, meet others, rest and eat in the street, their main activity is play and this use, as distinct from other uses, must be designed into the street to meet their needs (Simpson, 1999).

\section{PLANNING, URBAN GROWTH AND MANAGING URBAN ILLS}

Discussion on the rising social problems related to improper physical planning lead to the necessity of a more holistic approach to urban planning and to more

${ }^{3}$ According to World Health Organization (WHO) reports, 180 thousands child under the age of 15 killed every year due to road accidents. The majority of the victims $(96 \%)$ are from underdeveloped and developing countries. 
sensitivity towards the younger generation in urban spaces. Barnard (1980) acknowledges that children should be able to share all that cities have to offer, but too often cities are designed as worlds for adults by adults. The growth of cities and the mechanization of transport raise fears about the safety of children, particularly those children who walk to school or who play in the streets. This further reinforced the segregation of children, forcing them into schools, home, and playgrounds (if available). This justifies the statement that many public places were seldom designed with children in mind.

Children/teenagers, bored with the stressful living conditions, resort to spending their time with friends, loitering at nearby shopping complexes, internet cafes, and computer games arcades. This exposes them to various unhealthy activities and influences, in addition to minimizing their chances to enjoy the outdoors, fresh air, natural daylight and greeneries. As a consequence, cases of childabuse, runaways, drug abuse, school dropouts, vandalism, gangsterism and other forms of social problems are on the rise.

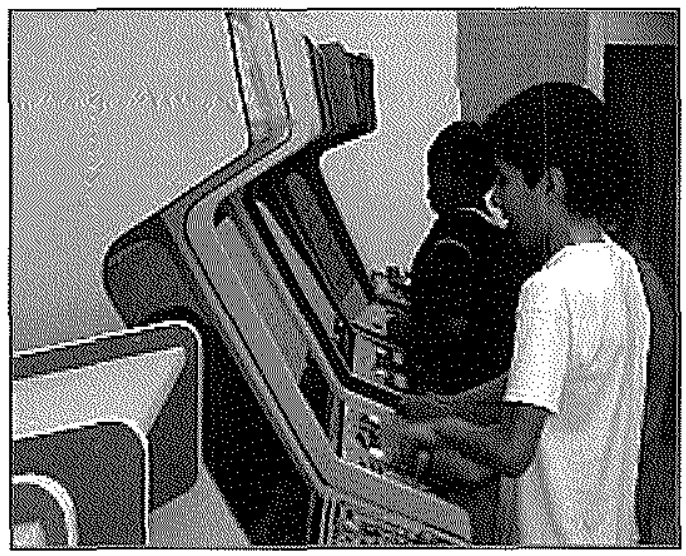

Figure 4: Arab children resorting to games arcades in shopping malls lead to more isolation and individualistic attitudes.

Contrary to those living in rural areas, Arab children in urban areas are more isolated, and individualistic. Even with the availability of social gathering points and appropriate public spaces, like community parks, more than $80 \%$ of the respondents of a field survey indicated that they never bring their children to nearby parks. Instead they prefer to bring their children to shopping complexes and mega malls in the city. 


\section{URBAN CHILDREN AND THE PHYSICAL ENVIRONMENT}

Children need a supportive physical environment to contribute to their optimal development. It is also true that children have some particular developmental needs that call for attention, such as the need for play. They can also be far more seriously affected by their living environments than adults are because of their greater vulnerability to disease and environmental hazards. For urban children in particular, the physical environment can present major problems, undermining their well-being and their prospects for the future. Some basic principles and guidelines need to be formulated and provided for local authorities to consider as they work to make their cities better places for children.

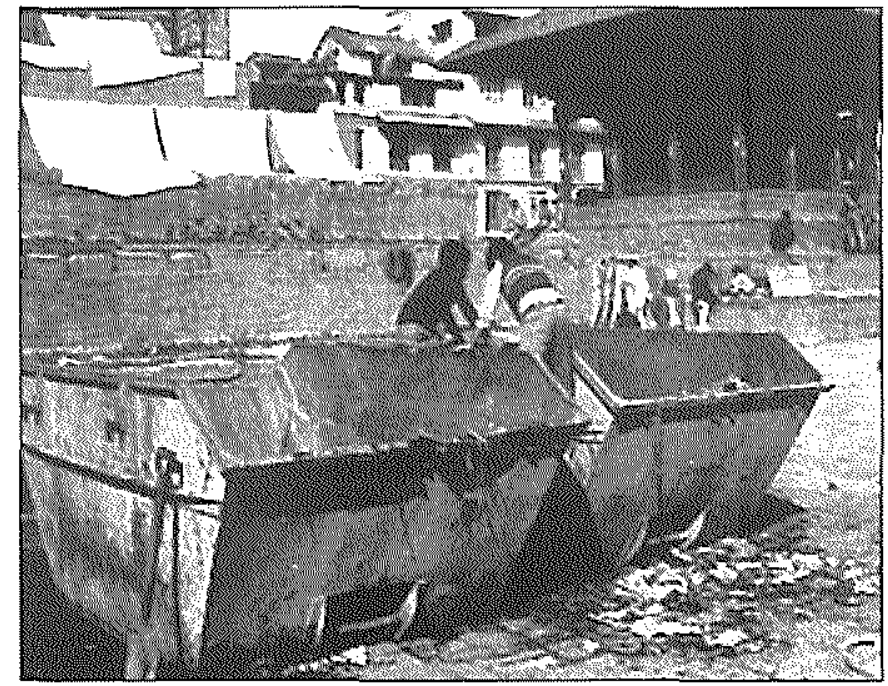

Figure 5: The suffering of children due to deteriorated urban conditions

Simpson (1999) suggests that one can find some instances of acceptance of the idea that children should be involved in the design of their urban environment. He further reminds that in urban planning the needs of children do not always coincide with those of adults. In this sense, a good approach that is worth mentioning here is the Japanese practice of "Machizukuri" (literally, "creating city') where local people, including children, take part and play their role in planning their living environment. 


\section{THE CONCEPT OF PLAY}

Children will play anywhere and with anything. It is the single most important activity in childhood that leads to both mental and physical development, and which gives satisfaction to the child if allowed to happen in an appropriate manner, at the appropriate time and in appropriate surroundings. (Friedberg, 1970) All the things that children do purely for joy are rightly called play, which is a constant happening and act of creation in the mind or in practice. Through the act of playing, there is a simultaneous and continuous two-way action between the child and his or her environment, with the environment providing the nourishment, and the child deciding what to digest from it. (Dattner, 1969) The outcome of this digestive process is specific to the unique personality of the child. Thus each child adds to the diversity of the environment and each child contributes to the total amount of nourishment available to the rest.
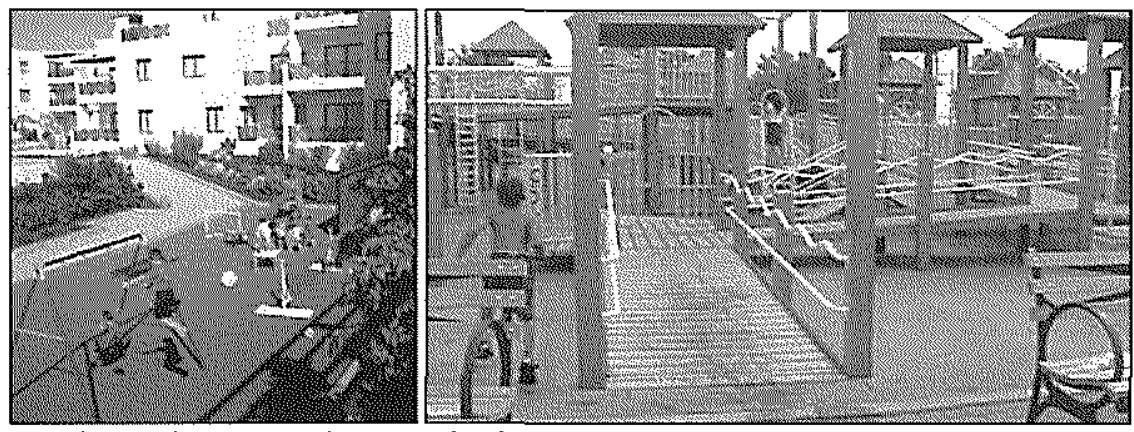

Figure 6: Protected, supervised and equipped children spaces are urgently required within livable residential neighborhoods.

Through play, children develop gross motor skills (physical mobility and muscle control) and fine motor skills such as eye-hand coordination - a critical precursor to reading and writing skills. Equally important, play helps makes learning fun! Play fuels children's imagination and sparks creativity, making the learning journey pleasurable and joyous. For many years, early childhood researchers have studied the role of play in the growth and development of children. They have found that "constructive play," like food, love, care and hope, is an essential building block for children - a critical part of the foundation children need to lead healthy, happy and productive lives. In order to create appropriate behavioral settings for play, the built environment must provide the child ample opportunities to create different kinds of secure territories for play as well as for active games. (Berne, 1964) In an appropriate play territory, children have the opportunity to digest their experience because 
the environment offers appropriate nourishment and is as familiar and defensible as the home range (Dattner, 1969).
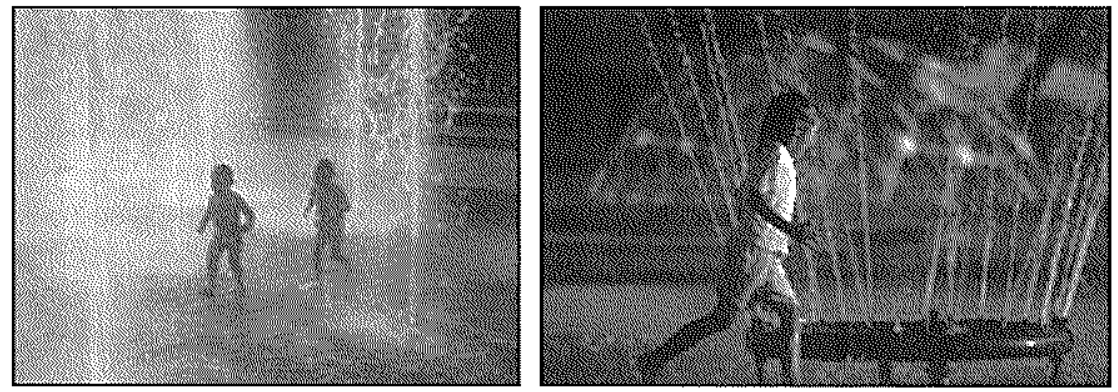

Figure 7: Regulated water elements can serve as focal points provoking the children desire to explore and also it helps in giving special character to places.

Children's need to play is a crucial part of their psychological and physical balance. It is often assumed that playgrounds are the best way to meet children's play needs. But playgrounds usually provide a limited range of possibilities (Hart, 2002). Play is something that needs to be available to children all day long, not just for a special event. Fortunately, even the poorest environments can be rich and stimulating places where children can play, provided they are safe.

\section{TODAY'S PLAY LANDSCAPE}

Children have more playtime choices today than ever before. There are classic toys, "high-tech interactive" toys, board games, organized sports and activities, video games, computer games, the internet and cable TV remotes that encourage channel surfing as a playtime activity. Unfortunately, in some cases these toys and media expose children to violent themes and contents. And in some cases, the media tend to encourage children to spend a considerable amount of time playing indoors, often by themselves - and often without the benefit of parental supervision as more parents work full-time today. With a more violent society in general today, playing outdoors unsupervised has nearly fallen by the wayside, especially for young children. In addition to missing out on valuable playtime experiences, limited outdoor play affects children's physical well-being. Experts believe that children do not get enough exercise today and this is cited as a leading factor in the rise of childhood obesity. 


\section{STREETS AS A PLAYGROUND}

A more recent observation of children's use of neighborhood streets in Arab cities describes the many possibilities for play that the street provides for slightly older children. There are piles of sand for digging in, hard surfaces for football and bicycles, building entrances to hide in, flights of stairs and retaining walls to climb. Children are observed jumping, climbing, skating, sliding, running, chasing, sitting and watching. Because alleyways are too narrow for cars, children could move freely back and forth between households, finding other children to play with, visiting local shops, watching people go about their business. On the other hand, not all urban areas in our contemporary Arab cities have streets that are safe. These observations may be overlooking the piles of waste and open drains that can make be major hazards to the health of young children.
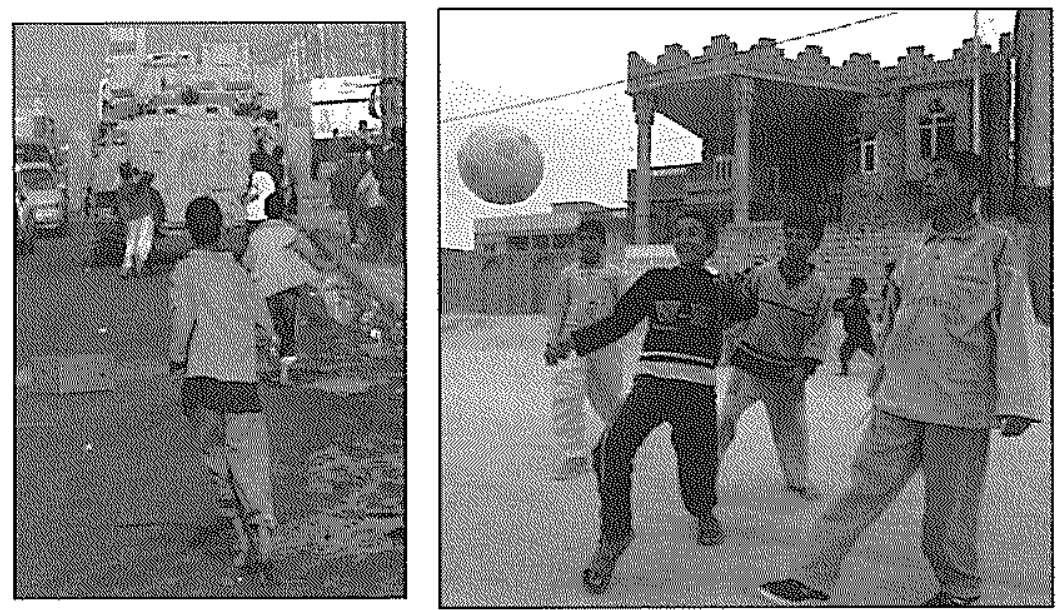

Figure 8: Street as a play ground even in the most dangerous urban zones, the case the occupied territories in Palestine \& Iraq.

When a new housing area is constructed or an old area is upgraded, the potential for play should always be considered. Measures that slow traffic, or eliminate it from some residential streets, can have dramatic effects. Both Britain and the Netherlands have some excellent examples of residential streets where children's need for play is given priority in various ways over the needs of cars (UNICEF, 2000). 


\section{BETWEEN FENCES: LIVING AND PLAYING IN A CONTEMPORARY CITY}

Most of the published research on the topic of children's outdoor play that has been conducted in many countries (Alexander, 1977; Gehl, 1996; Freeman, 1995; Moore, 1989; Watkins, 1980; Churchman, 1999) have shown that the environmental characteristics important for outdoor playing spaces can be summarized as follows:

- Spaces are close to home and close to entrances that are used by adults.

- Densities that allow children to find many playmates within walking distance.

- Easy accessibility to spaces, both visually and physically.

- Proximity to other activities, particularly those of adults.

- Having sufficient open space to allow children to undertake activities like ball games, bicycle-riding etc.

- Accommodating the interests and abilities of different children's ages, gender, and cultural/social backgrounds.

- Providing play equipments appropriate for different ages and different activities. In addition, these equipments should offer varying levels of challenge.

- Providing flat and hard-surface areas that fit most of the activities that children engage in, in addition to natural areas.

- The spaces should include elements that are responsive to children's actions.

- Spaces are safe in terms of traffic, ground surfaces, equipments and also safety from adults.

- Spaces should be comfortable climatically for as much of the year as possible.

- A consideration should be directed towards adults, both those who may be supervising the children, and those who are living close to the play areas.

According to the findings of the above mentioned published work, these characteristics are to a large extent present in the streets of neighborhoods and small towns, rather than in the local formally provided playgrounds. In addition, it cannot be achieved in the form of regular playgrounds, which are the most common solution proposed by planners and urban designers (adults). Rather they require all of the outdoor spaces of the residential environment be planned and designed in such a way that children can enjoy the act of play in them. In this view, playgrounds are only one part of this system of open spaces for children. 


\section{CHILDREN'S PARTICIPATION IN CITY DEVELOPMENT PROCESS}

What is lacking in the city, a fault inherent in the planning process itself, is respect and an understanding of the actual needs and perceptions of the children for whom facilities are designed. Cities become virtually unworkable when planned for a few specific phases of life. As social equity is one of the key issues in creating the public realm, the voice of children, the most vulnerable section of society, must be heard alongside with the other sections.

Giving voice to children and young people's experience of place should be seen as a crucial phase in the process of community development. As Percy-Smith (1999), has argued children's participation in local decision-making constructs a major challenge for authorities and local governances. The value of supporting and evaluating children's participation in the development process needs to be examined. A series of fundamental questions need to be addressed; such as what happens when children participate in community development?, what are their own believes and attitudes about their participation?, how can organizations know that participatory processes are in fact in the best interests of the children themselves and the settings of which they are a part?, and how can governments and organizations effectively support the most beneficial forms of participation?

Children should have a say in the kind of environments in which they want to live, learn and play. They have a dynamic vocabulary of metaphors through which they can transform and ascribe meaning to mundane everyday objects. This realm of metamorphic operations needs to be explored in order to generate truly child-friendly places. Children have a world of their own and it is often difficult for adults to match the strength of their imagination. If this is introduced in the design and planning process, it will address the physical structure of community planning as well as those aspects affording spontaneous human support. This is because children perceive and use the environment as a direct outcome of their actual needs and way of life without self-consciousness.

In fact, as Bratlett (2002) has argued, projects from around the world, which have drawn on children's participation in decision-making about their neighborhood surroundings, have indicated how seriously they respond to the opportunity to offer their views. Their suggestions are usually well-considered and insightful, often pointing to issues that adults might overlook or dismiss, but which are nonetheless important. The marginalization of children and young people in the process of planning and designing their neighborhoods has negative implications on their sense of citizenship and belonging. There is no better way for children to learn about the responsibilities of citizenship and to gain a sense of their own capacity to contribute than by helping to shape the 
environments that they use every day and that they depend on for their own well-being (Hart, 1997).

\section{CHILDREN AND SUPPORTIVE NEIGHBOURHOODS}

As children grow older and become more competent, they are naturally drawn to move further from home and to rely increasingly on their neighborhoods for companionship, stimulation and experience. A good neighborhood enhances development on every front by providing a richness of settings, relationships, and opportunities that can engage children's minds, enlarge their social world and contribute to their skills, understanding and developing identity. A good neighborhood is one that makes it inviting and possible for children to move safely into this larger, more complex world and that supports their development as contributing citizens.

It is a place where people of all ages can interact with one another, where groups of friends can gather to talk and socialize, where children and young people can move about freely and safely, where there are some shared values and goals that include every one, and where it is possible for a community to enjoy the activities and rituals that define it. By contrast, neighborhoods that leave children and young people feeling alienated and unsupported are those where they are socially excluded, or geographically isolated from opportunities; where they lack transportation; where they are bored, where they are fearful of harassment and crime; where traffic dominates, and where there is a general sense of neglect. As Chawla (2002) has emphasized, children are quick to point to disrepair and lack of basic services, and to see these physical conditions as a humiliating reflection of their own worth.

\section{CREATING CHILD-FRIENDLY CITIES}

\section{Principles, Patterns and Guidelines for Child-Friendly Cities}

\begin{tabular}{|c|c|}
\hline Principles & Patterns And Guidelines \\
\hline $\begin{array}{l}\text { Security, } \\
\text { Safety, and } \\
\text { Supervision. }\end{array}$ & $\begin{array}{l}\text { - Safe contained spaces close to home. } \\
\text { - Spaces close to adults who can keep a watchful eye } \\
\text { as they work or socialize. } \\
\text { - Protection from traffic. } \\
\text { - Enhance public awareness programmes about } \\
\text { children's safety and need for protection. } \\
\text { - Lighting for places where children's evening play. }\end{array}$ \\
\hline
\end{tabular}




\begin{tabular}{|c|c|}
\hline $\begin{array}{l}\text { Diversity and } \\
\text { Opportunities }\end{array}$ & $\begin{array}{l}\text { - Engage children in the planning and design } \\
\text { process. } \\
\text { - Easy contact with other children. } \\
\text { - Spaces to allow running and chasing. } \\
\text { - A flexible environment that can be shaped and } \\
\text { changed by children. } \\
\text { - Allow children with disabilities to be with other } \\
\text { children. } \\
\text { - Places to hide "Secret Places". } \\
\text { - Age appropriate challenge without danger. } \\
\text { - Green and Natural Environment. }\end{array}$ \\
\hline $\begin{array}{l}\text { Features of } \\
\text { Playgrounds }\end{array}$ & $\begin{array}{l}\text { - Many small spaces, close to where children live, } \\
\text { are better than one large far place. } \\
\text { - Accessible to all ages and special needs. } \\
\text { - Accommodating adults to sit and socialize. } \\
\text { - Using trees as playing centers. } \\
\text { - Away from traffic and pollutants. }\end{array}$ \\
\hline $\begin{array}{l}\text { Children's } \\
\text { Mobility }\end{array}$ & $\begin{array}{l}\text { - Create cycle tracks. } \\
\text { - Frequent and safe crossings. } \\
\text { - Install speed pumps, and reduce speed limits. } \\
\text { - Make sidewalks wider. } \\
\text { - The presence of public transportation. }\end{array}$ \\
\hline $\begin{array}{l}\text { Public Spaces } \\
\text { and Streets }\end{array}$ & $\begin{array}{l}\text { - Network of squares, parks and natural areas. } \\
\text { - Community places to meet and socialize. } \\
\text { - Increase pedestrian areas and paths. } \\
\text { - Integrate children and young people spaces with the } \\
\text { life of their communities. } \\
\text { - Connected play areas. } \\
\text { - Allowing children to explore the city via safe streets } \\
\text { - Streets as an educational experience. }\end{array}$ \\
\hline
\end{tabular}

\section{CONCLUSION}

- Many of the urban problems that Arab cities experience today result from an unbalanced approach to development, where physical development has been given priority compared to social development.

- Urban authorities need to be sensitive to the needs of urban children and they need to find suitable tools and mechanisms to involve children in designing 
their environment. Towns and cities must be made safe and children friendly.

- Children today are smarter than before. They are more independent, isolated, more demanding, and more individualistic. Through good urban design, urban change can be made to respond to the needs of less advantaged groups, by distributing benefits through neighborhoods that are made accessible, satisfying and empowering to users. These should be well connected to the rest of the city and provide a safe and educative environment for all children and adolescents.

- The roles of urban planning have evolved from laying out basic facilities, zoning specific land uses, future plans for towns and cities into specific designs of urban spaces for a more sustainable environment. The paper illustrates how physical environment can influence the social upbringing of urban dwellers, especially the younger generation.

- Opportunities for play are very important for every child but special efforts must be made to ensure access to an evolving environment for children with disabilities, of whatever kind.

\section{REFERENCES:}

Alexander, Christopher, 1977. A Pattern Language. Oxford University Press: N.Y.

Barnard, J., 1980. Children in the Built Environment: Guidelines for Planning and Design. Georgian House: Melbourne

Bartlett, S., 2002. Urban Children and the Physical Environment. Proceedings of International conference on children and the city, Amman, Jordan. UNHabitat publications

Chawla, L. (Ed.), 2002. Growing Up in an Urbanizing World. Paris/London: UNESCO Publishing / Earthscan.

Chawla, Louise \& Salvadori, 1., 2002. Children for Cities and Cities for Children. In A. Berkowitz \& C. Nilon (Eds.), Understanding Urban Ecosystems, Ney York: Springer- Verlag.

Christensen, Pia \& O'Brien, M., 2002. Children in the City. London: Routledge.

Driskell, D., 2002. Creating Better Cities with Children and Youth. A Manual for Participation. Paris/London: UNESCO Publishing / Earthscan.

Freeman, C., 1995. Planning and Play: Creating Greener Environments, Children's Environments, 12(3), pp.381-388. 
Gatto, J., 2003. Educating Your Child In Modern Time. California: Alhambra Productions, Inc.

Gehl, J., 1996 Life Between Buildings. Copenhagen: Arkitektens Forlag. Harel, I., 1991. Children Designers. Norwood, NJ: Ablex Publishing Hart, R., 1997. Children's Participation: The theory and Practice of Involving Young Citizens in Community Development and Environment Care, London: UNICEF publishing / Earthscan.

Hart, R., 2002. Containing Children; some lessons on planning for play from New York City. Environment and Urbanization 14(2), 135-148

Horelli, L., 1994. Children as Urban Planners. Architecture and Behavior, 10(4), pp.371-378.

Lynch, Kevin., 1977. Growing up in Cities. Cambridge, MA: MIT Press.

Lynch, Kevin., 1997. The Spatial World of Children. In W. Michelson \& S. Levine (Eds.), The Child in the City, Vol. 1, University of Toronto Press, pp.102-127.

Mohamed, Badaruddin., 2002. Planning for the Children of the future. In Proceedings of International conference on children and the city, Amman, Jordan. UN-Habitat Publications.

Moore, R., 1989. Playgrounds at the Crossroads. In I. Altman \& E. Zube (eds) Public Places and Spaces. N.Y.: Plenum.

Percy-Smith, Barry, 1999. Multiple Childhood Geographies: Giving Voice to Young People's Experience of Place. Unpublished Doctoral Thesis, University College Northampton, UK.

UNICEF., 2000. Poverty and Exclusion Among Urban Children. Innocenti Digest. Florence, Innocenti Research Center, UNICEF.

UNICEF., 2007. State of the World's Children. New York: UNICEF

Simpson, Brian., 1999. Towards the Participation of Children and Young People in Urban Planning and Design. Urban Studies. Vol.34 Issue 5/6.

Spencer, C. \& Woolley, H. 1998. Children and the City: a summary of recent environmental psychology research. In Child: Care, Health and Development, 26(3), pp.181-198.

Taylor, A.F., A. Willy, et al. 1998. Growing up in the inner city: Green Spaces to Grow. Environment and Behavior, 30(1), pp. 3-27.

Taylor, Anne, 1987. Architecture and Children. Curriculum Posters. New Mexico: School Zone, Inc.

Ward, C., 1978. The Child in the City. New York: Pantheon.

Watkins, W., 1980. Play Environments in Arid Lands. In P. Wilkinson(ed) Innovations in Play Environments, N.Y.: St. Martin's Press. pp 97-102. 


\section{Internet:}

UNICEF http://www.UNICEF.org

UNISCO http://www.UNESCO.org

Global Knowledge: http://www.globalknowledge.org/

Judge, Paul. Slum Children and Computers.

http://www.school.za/news/pr/20000302-

slumchildrencomputers.htm

Mitra, Sugata. Rana, Vivek. Children and the Internet:

http://www.geocities.com/SoHo/1718/docs/children.html

Teaching and learning through design, creativity and technology:

http://www.csupomona.edu/ dnelson/

Children protection Initiative (CPI-MENA) http://www.mena/cpi.org 
